\title{
Financial and economic security system strategic management as an independent direction of management
}

\author{
Oleksandr Cherevko ${ }^{1}$, Serhiy Nazarenko ${ }^{2}$, Nataliia Zachosova ${ }^{2, *}$, and Nataliia Nosan $^{3}$ \\ ${ }^{1}$ Bohdan Khmelnytsky National University of Cherkasy, Department of the Enterprise Economics, Accounting and Audit, Cherkasy, \\ Ukraine \\ ${ }^{2}$ Bohdan Khmelnytsky National University of Cherkasy, Department of Management and Economic Security, Cherkasy, Ukraine \\ ${ }^{3}$ Cherkasy State Technological University, Department of Economics and Entrepreneurship, Cherkasy, Ukraine
}

\begin{abstract}
The scientific views of domestic researchers regarding the definition of financial and economic security using the basics of the systematic approach are generalized. The author's vision on the definition of financial and economic security system is proposed. The main shortcomings of existing approaches to the process of formation of financial and economic security system as an object of management are revealed and systematized. The main defects and miscalculations in security management both - at the micro and macro levels are identified. The 16-component model of management of financial and economic security (PROM) was proposed. The conceptual foundations of security oriented strategic management are specified. Three strategies offered for achieving economic and financial security: Strategy for achieving financial and economic security on the basis of branding, image and reputation (BIR strategy), Strategy for achieving financial and economic security through partnerships with stakeholders and ensuring their interests (Strategy of PIS), Strategy for achieving the state of financial and economic security through the interconnection of experts, control and standardization (Strategy of ECS).
\end{abstract}

\section{Financial and economic security system management as an objective requirement of time}

Increasing the number of threats in the external and internal environment of the functioning of modern micro and macro-level economic systems leads to the need for transformation and complication of the processes of managing their financial and economic security. In general, the awareness of the need for the introduction of safe-oriented management practices at the theoretical, methodological and applied level took place relatively recently. The security science in Ukraine began to develop vigorously after the global financial crisis of 2008 - until then, the problem of ensuring the economic security of business entities and of the state as a whole was reflected in certain areas of research of scientists within the framework of other economic branches of science. At the applied level, issues of economic security were also not a priority for owners and top management of business structures. In order to achieve the main goal of the business - to make a profit - it was enough to perform qualitatively all planned vectors of the main, financial and investment activity, periodically resorting to risk management tools. On a national scale, the issues of state security aggravated in the period of 2005-2006, and this became the reason for the adoption in 2007 of the National Security Strategy of Ukraine. According to this document, Ukraine should in the long term become a "democratic state with a stable and growing market economy" [1], and appropriate measures should be developed to counteract the main threats to its economic security which were specified in this document. However, this did not happen, and as in 2007 global security crisis became a trigger for developing a security strategy, in 2015, its new edition saw the world because of the Revolution of Dignity (2014). It's a pity to realize that the catalysts for economic transformations in Ukraine are only openly negative phenomena and events, both national and global ones. In periods of absence of force majeure, the government does not call for the initiation of reforms in the mechanisms of ensuring financial and economic security at different levels of organization and implementation of economic processes. This testifies to the revolutionary rather than evolutionary nature of the development of domestic national political and economic systems, which is usually accompanied by destruction, leveling of previous achievements, chaos and a long period of restoration before the beginning of positive changes.

In the National Security Strategy 2015, the goals of which are relevant nowadays, in the beginning of 2019, since the document has not lost its validity at the moment, it is declared the necessity of "dynamic development of the Ukrainian economy ... by providing sustainable social, political and socio-economic development" [2]. And if in the Strategy of 2007 its creators identified five main threats to the state of economic security of the national economy, then in the Strategy of 2015 their number has increased to ten $[1,2]$, which indicates a lack of success in the implementation

*Corresponding author: natazachosova@gmail.com 
of security-oriented vectors of management of the state economic system.

Thus, there is an urgent need to review the fundamental principles of economic security management of the state and of the economic entities, as well as its financial component at the theoretical and methodological level in order to obtain a qualitative information and analytical basis for the adoption of timely and effective management decisions regarding the vectors of modern economic systems development in the full range of risks and threats to the environment of their functioning in the short-term and strategic perspectives.

\subsection{Scientific approaches to the understanding of the content essence of the concept of financial and economic security}

In ensuring financial and economic security both at the state level and at the level of a economic entity or individual, systematic approach should take place. Financial and economic security is a complex concept in the theoretical plane of content and multielement structure as an object of management. In the understanding of the system of financial and economic security at the macro and micro levels there are differences, because each of them has its own specificity and characteristics that should be reflected in the proposed definitions of the category under study.

The system of financial and economic security over the last decade has been and remains an actual object for scientific research. By studying the history of the formation of a categorical basis for the management of financial and economic security, one can conclude that there are several dominant approaches to the interpretation of this process. Their establishment took place in a scientific environment, where there was a continuous debate about whether to study economic security separately from its financial component, or to combine them into a single scientific definition and considered as a coherent system in the context of state governance or corporate management. Foreign sources present financial and economic security as a macroeconomic category [3-7]. At the level of an enterprise, financial and economic security is often understood as a certain state (for example, of the resources and economic opportunities of an enterprise on the way to the realization of the purpose of its activity and ensuring satisfaction of interests of stakeholders) as a function (of resource provision or resource potential supply) or as a property to continue profitable activity [8, p. 286] O. Cheberyako and M. Kryvovyaz offer to understand the system of financial security of the enterprise as "a set of interconnected elements, subsystems, financial instruments, leverages, methods and measures aimed at the timely detection and neutralization of crisis phenomena in order to ensure a stable and efficient activity" [9, p. 95]. We believe that this approach simply understanding of financial and economic security, since measures for its provision should be initiated only in a situation when the subject of economic activity is experiencing the beginning of the onset of the crisis or its consequences. Crisis prevent is a task of crisis management, and the proposed definition implies that the management of financial and economic security should be considered as an element or direction of crisis management, while we support the idea of separating management of financial and economic security into an independent management direction [10].

O. Kopylyuk, O. Muzychka believe that "the system of financial and economic security of business structures involves a set of interrelated administrative measures of organizational, legal, financial and economic nature, which are implemented by the authorized bodies, services, units of the business entity and aimed at protecting its interests from illegal actions by real or potential carriers of threats that could lead to significant economic losses and destabilize tactical and strategic objectives to increase competitive advantage and to develop future economic growth" [11, p. 106-107]. The proposed definition is interesting from a practical point of view, since it gives an indication to the subjects of the provision of financial and economic security on the need to direct the management influence not to the actual threat, its negative impact or its consequences, but to the sources of the emergence and existence of such threats. In addition, the definition contains a reference to the importance of taking into account the strategic objectives of the entity in developing and implementing measures to maintain an appropriate level of its financial and economic security, which proves the rationality of comprehensive research on the issues of strategic management of financial and economic security of the business entities. From the standpoint of O. Kvasova, the system of financial and economic security of the enterprise is a "set of interconnected elements, subsystems, financial instruments, methods and measures that ensure the safety of the enterprise and the achievement of its main objective of activity" [12, p. 72]. Such a definition can be considered a "base model", the so-called "model of basic equipment" for explaining the essence of the system of financial and economic security in security science. Indeed, it contains general concepts and characteristics that need to be specified to describe the content of financial and economic security, taking into account the specifics of research objects. However, it should be noted that the proposed definition does not mention the need to achieve a state of satisfaction of the interests of various categories of stakeholders of the entity, however, it is likely that the author includes their implementation in the purpose of the enterprise.

The concept of an integrated system of financial and economic security has also been disseminated in the scientific sphere. Its content is reduced to "a set of interrelated measures of organizational, economic and regulatory nature, which are implemented in order to ensure the protection of the results of enterprises or financial institutions from the negative effects of various kinds of real or potential actions of individuals or legal entities, which may lead to the emergence of significant economic losses" [10]. The similarity in the content interpretation with the source [11] is observed. This makes it possible to distinguish a comprehensive approach to the definition of the essence of financial and 
economic security system in the field of modern security science. The logical use of the category "financial and economic security" instead of two separate concepts "economic security" and "financial security" is reasonably proved in scientific research by M. Lohvinenko and A. Borysova, emphasizing that "economy" and "finance" are interdependent concepts, the latter is a "constituent instrument of the first ... "economic security" is a concept broader than "financial security", because financial security is an integral part of economic security in general ... the financial component has a certain "priority" among all others ... the leading role of financial security is felt at all stages and levels of its provision ... financial security regulates issues of financial and economic prosperity of economic entities and their stability to prevent bankruptcy. This confirms the importance of determining "financial security" through the prism of "economic security" [13, p. 620].

At the state level, the concepts of financial security and economic security are clearly divided. Under economic security, the government structures understand "the state of the national economy, which allows them to remain resistant to internal and external threats, to ensure high competitiveness in the global economic environment and characterizes the ability of the national economy to sustainable and balanced growth" [14, p. 2]. Financial security is a "state of the financial system of the country, which creates the necessary financial conditions for a stable socio-economic development of the country, ensures its stability to financial shocks and imbalances, creates conditions for the preservation of the integrity and unity of the financial system of the country" [14, p. 3]. Thus, regulatory documents do not leave space for a free interpretation of financial and economic security as a single concept, however, domestic scientists demonstrate author's position regarding the specification of its constituents. The financial security of the state is "an important component of its economic security, such a state of existence of the country, in which it is possible to provide sufficient amounts of financial resources for its stable development in the long run, to meet the priority financial needs, and to facilitate the formation of prerequisites for the effective development of the national economy" [15, p. 189]. The indication of the need to take into account long-term vectors of economic development while ensuring the financial and economic security of the state confirms the urgency of the problem of strategic management and economic and financial security at the macro level.

In Table 1 generalized features of existing approaches to understanding the essence of the system of financial and economic security.

We believe that the system of financial and economic security is a set of elements, the interaction of which between themselves and with external actors can form such an environment of the functioning of a particular object, which will enable it to achieve the economic goal of its creation and implementation of the economic and financial interests of its stakeholders, regardless the existence and negative impact of threats on its current state and performance. Coordination of the interaction vectors of the selected list of elements for building a system of financial and economic security is the goal of the process of managing it.

Table 1. Scientific views on the definition of financial and economic security within a systemic approach [summarized by authors].

\begin{tabular}{|c|c|c|}
\hline Approach & $\begin{array}{l}\text { For business entities } \\
\text { (micro level) }\end{array}$ & $\begin{array}{l}\text { For the state } \\
\text { (macro level) }\end{array}$ \\
\hline \multirow{4}{*}{$\begin{array}{l}\text { Security as } \\
\text { a condition } \\
\text { of }\end{array}$} & \multicolumn{2}{|c|}{ absence of dangers } \\
\hline & \begin{tabular}{|c|} 
availability of sufficient \\
corporate resources
\end{tabular} & $\begin{array}{l}\text { availability of sufficient } \\
\text { resources for the needs of } \\
\text { the national economy }\end{array}$ \\
\hline & $\begin{array}{c}\text { achieving the economic } \\
\text { goal of creation }\end{array}$ & $\begin{array}{c}\text { satisfaction of economic } \\
\text { and financial needs of } \\
\text { business and society }\end{array}$ \\
\hline & \multicolumn{2}{|c|}{$\begin{array}{c}\text { protection from hazards, threats of risks and their } \\
\text { negative impact }\end{array}$} \\
\hline \multirow{4}{*}{$\begin{array}{c}\text { Security as } \\
\text { a } \\
\text { opportunity } \\
\text { for }\end{array}$} & \multicolumn{2}{|c|}{ counteracting dangers, threats, risks } \\
\hline & \begin{tabular}{|c|} 
gaining competitive \\
advantages in the market
\end{tabular} & $\begin{array}{l}\text { improving the level of } \\
\text { economic freedom }\end{array}$ \\
\hline & \multicolumn{2}{|c|}{ increase of investment attractiveness } \\
\hline & \multicolumn{2}{|c|}{$\begin{array}{c}\text { creation of conditions for financial and economic } \\
\text { development }\end{array}$} \\
\hline \multirow{3}{*}{$\begin{array}{l}\text { Security as } \\
\text { a sign of, } \\
\text { ability to }\end{array}$} & \begin{tabular}{|c|}
$\begin{array}{c}\text { stable and cost-effective } \\
\text { operation }\end{array}$ \\
\end{tabular} & balanced economic policy \\
\hline & $\begin{array}{c}\text { high level of economic } \\
\text { development and } \\
\text { capacity }\end{array}$ & $\begin{array}{l}\text { effective allocation of } \\
\text { national resources }\end{array}$ \\
\hline & \multicolumn{2}{|c|}{$\begin{array}{l}\text { control of the adverse effects of hazards, threats and } \\
\text { risks and the ability to compensate for it }\end{array}$} \\
\hline \multirow{4}{*}{$\begin{array}{l}\text { Security as } \\
\text { a condition } \\
\text { of }\end{array}$} & $\begin{array}{l}\text { financial stability and } \\
\text { independence }\end{array}$ & $\begin{array}{l}\text { financial and economic } \\
\text { sovereignty }\end{array}$ \\
\hline & $\begin{array}{c}\text { further activities without } \\
\text { the risk of bankruptcy } \\
\text { and liquidation }\end{array}$ & $\begin{array}{l}\text { recognition in the } \\
\text { international economic } \\
\text { arena and in the global } \\
\text { financial system }\end{array}$ \\
\hline & $\begin{array}{l}\text { the ability to satisfy } \\
\text { stakeholders' interests }\end{array}$ & $\begin{array}{l}\text { the ability to satisfy } \\
\text { national economic } \\
\text { interests }\end{array}$ \\
\hline & \multicolumn{2}{|c|}{ positive image and reputation } \\
\hline \multirow[t]{4}{*}{$\begin{array}{l}\text { Security as } \\
\text { a result of }\end{array}$} & \multicolumn{2}{|c|}{$\begin{array}{c}\text { rational use of resources and entrepreneurial } \\
\text { opportunities }\end{array}$} \\
\hline & \begin{tabular}{|c|} 
an effective combination \\
of tools for financial, \\
crisis and risk \\
management
\end{tabular} & $\begin{array}{l}\text { an effective system of } \\
\text { financial monitoring, } \\
\text { supervision, control, } \\
\text { regulation }\end{array}$ \\
\hline & $\begin{array}{l}\text { rejection of risky } \\
\text { activities }\end{array}$ & $\begin{array}{l}\text { conducting a successful } \\
\text { economic and financial } \\
\text { policy }\end{array}$ \\
\hline & $\begin{array}{c}\text { weighted management } \\
\text { decisions }\end{array}$ & $\begin{array}{c}\text { implementation of the } \\
\text { national security strategy }\end{array}$ \\
\hline
\end{tabular}

As the purpose of forming and further functioning of the system of financial and economic security, L. Holovkova and A. Yakimova consider "timely detection and prevention of both internal and external hazards and threats, ensuring the security of the enterprise and achieving its corporate goals" [16, p. 57]. It should be noted that if management seceded to identify threats and risks in a timely manner and developed a set of measures for preventive response to them, the process of management of financial and economic security is set up flawlessly, and its system is perfect. However, in practice, such cases are not 
mentioned. Therefore, the purpose of the existence of the system of financial and economic security is to create such a medium for conducting economic activity of the micro or macro-level system, in which it would be possible to identify the risks, threats and risks in time, to prevent the maximum reduction of their number and to minimize the negative effects of those species, which action prevent is completely impossible. The rationality of the organization of the system of financial and economic security is precisely measured by the ratio of resources spent on security measures and the costs that would have been incurred in the event of inactivity in this direction.

\subsection{Financial and economic security in modern conditions: an emergent system as an object of management}

In the conditions of total absence of both - business entities and the state as a whole - resources that could be directed towards the formation of integrated systems of financial and economic security, it is very important to choose security priorities and to organize the structure of its system so that it envisaged in it the functional components corresponded to these priorities, and also directed the allocated resources to counter the threats, the impact of which could be most tangible and ultimately critical. Therefore, we will study the existing approaches to the definition of elements of financial and economic security systems. Studying the peculiarities of financial and economic security management in the management system of a trading enterprise, S. Hrinkevych and M. Koknayeva distinguish seven components of financial and economic security: financial, commercial, market, informational, personnel, organizational, structural, technical and technological [17]. For financial institutions, scholars advise to provide for the existence of such subsystems of an integrated system of economic security, such as financial and investment, intellectual and personnel, information and analytical, technical and technological, physical (power), legal, territorial, market, legislative and political [10, p. 47-48]. In this approach, at least three subsystems are strongly influenced by the external environment, so managing them at the level of the economic structure will be limited and complicated by the inability to influence certain economic realities.

Research of numerous scientific sources makes it possible to conclude the classical set of subsystems of a complex system of financial and economic security: financial (as a separate subsystem), personnel, intellectual, informational, analytical, technical, technological, investment, market, legal, industrial, ecological, normative (legislative), social, power (physical), interface, energy, innovation, material, resource, labor safety, reputation. This list can be supplemented with the image component, which is intended to strengthen the level of trust of existing and potential customers to the products and services of the business entity, but it can also be distinguished as a functional subsystem of the second level in the composition of the interface or reputation component.

The system of economic security of the state, taking into account the nationally adopted in 2013, methodological recommendations for calculating the level of economic security of Ukraine contains such components as industrial, demographic, energy, foreign economic, investment-innovation, macroeconomic, food, social and financial security. The latter also has subsystems, such as banking security, the security of the non-banking financial sector, debt security, fiscal security, currency security and monetary security [14]. There are some thoughts on the need to identify the military-economic (quite relevant for Ukraine from the end of 2013 to the present time), scientific, mineral-raw material, technological, informational (relevant due to the long hybrid war against Ukraine) and property security (also very relevant component, taking into account the state of the business climate in Ukraine and the organization of the protection of property rights in the normative plane and in practice). O. Mischuk believes that the organization of the system of financial and economic security of economic entities should be based on the principles of scientific validity, strategic validity, planning, targeting, and optimality [18]. There are no objections and arguments against using this list of principles and at the level of management of financial and economic security of the state. The list can be supplemented by the following principles of constructing economic systems, such as complexity (system), sufficiency, rationality, continuity, priority, legitimacy, timeliness, interaction, competence, combination of publicity and confidentiality, coordination, flexibility, independence and responsibility, centralization of management, control, activity, specialization, improvement, priority of prevention measures, etc. [19]. We believe that a specific set of principles for the organization and functioning of the system of financial and economic security should be selected taking into account the available resources, as well as in view of the type of chosen security system (Table 2).

The lack of unity in addressing the question of what the structure of an integrated macro-level or micro-level system of financial and economic security should be, on the one hand, complicate the process of its formation at the application level, while, on the other hand, it provides the flexibility of its architecture and the practical application of such systems providing financial and economic security that will be focused on the specific functioning of a particular subject.

The system of financial and economic security belongs to the category of emergent systems, because it demonstrates more complex qualities and characteristics than its separate functional subsystems.

In addition, the system gets new quality depending on the specifics of the subject for which it was formed an industrial enterprise, financial institution, state, etc. Immergence as a property of the system of financial and economic security affects the organization of its management process, which does not always take into account top managers of companies and civil servants. Therefore, the problem of effective management of 
financial and economic security at the micro and macro level does not lose its relevance. Of particular interest is the specifics of strategic security management, taking into account the complexity of forecasting hazards, threats and risks and their possible impact on the resources and interests of economic systems in the medium and long term.

Table 2. Disadvantages of modern approaches to the formation of the system of financial and economic security as an object of management [summarized by authors].

\begin{tabular}{|c|c|c|c|}
\hline Disadvantages & $\begin{array}{l}\text { Universal } \\
\text { system }\end{array}$ & $\begin{array}{c}\text { Specific- } \\
\text { oriented } \\
\text { system }\end{array}$ & $\begin{array}{c}\text { Fragmentary } \\
\text { system }\end{array}$ \\
\hline $\begin{array}{l}\text { Absence of a } \\
\text { clearly in } \\
\text { defined list of } \\
\text { functional } \\
\text { subsystems }\end{array}$ & $\begin{array}{c}\text { Contains as } \\
\text { many } \\
\text { subsystems } \\
\text { as possible, } \\
\text { even if their } \\
\text { presence is } \\
\text { not critical to } \\
\text { the object } \\
\text { security }\end{array}$ & $\begin{array}{l}\text { Contains the } \\
\text { subsystems that } \\
\text { are required for } \\
\text { a particular } \\
\text { security object, } \\
\text { but they are not } \\
\text { always } \\
\text { professionally } \\
\text { organized and } \\
\text { functional }\end{array}$ & $\begin{array}{c}\text { Contains a set } \\
\text { of most } \\
\text { traditional } \\
\text { subsystems of } \\
\text { the financial } \\
\text { and economic } \\
\text { security } \\
\text { system, the } \\
\text { connections } \\
\text { between them } \\
\text { are often } \\
\text { violated and } \\
\text { ineffective }\end{array}$ \\
\hline $\begin{array}{c}\text { Unregulated } \\
\text { rights and } \\
\text { obligations of } \\
\text { the subjects of } \\
\text { the system }\end{array}$ & \begin{tabular}{|c|} 
Security \\
actors rely \\
on too many \\
diverse \\
functions
\end{tabular} & \begin{tabular}{|} 
Rights and \\
responsibilities \\
are divided \\
according to \\
areas of \\
responsibility, \\
but the \\
emergence of \\
sudden \\
additional tasks \\
causes panic \\
and chaos \\
\end{tabular} & $\begin{array}{l}\text { The performers } \\
\text { do not have a } \\
\text { clear list of } \\
\text { functions, they } \\
\text { perform tasks } \\
\text { that particular } \\
\text { moment in } \\
\text { time require }\end{array}$ \\
\hline $\begin{array}{l}\text { Methodological } \\
\text { inconsistency in } \\
\text { the assessment } \\
\text { of the system } \\
\text { state }\end{array}$ & \begin{tabular}{|} 
The fact of \\
the security \\
system is \\
emergent \\
one is not \\
taken into \\
account, and \\
the \\
evaluation of \\
its condition \\
is carried out \\
by summing \\
up the \\
assessments \\
of the states \\
of all its \\
subsystems
\end{tabular} & \begin{tabular}{|} 
The need for \\
introducing \\
additional \\
evaluation \\
parameters and \\
expert \\
invitations, \\
taking into \\
account the \\
specific \\
structure of the \\
system
\end{tabular} & $\begin{array}{c}\text { There is no } \\
\text { periodicity of } \\
\text { evaluation, and } \\
\text { a set of } \\
\text { indicators and } \\
\text { subjects for } \\
\text { analytical work } \\
\text { are selected } \\
\text { depending on } \\
\text { which } \\
\text { subsystems are } \\
\text { present, often } \\
\text { the evaluation } \\
\text { is not done by } \\
\text { specialists in a } \\
\text { particular field }\end{array}$ \\
\hline $\begin{array}{l}\text { Lack of } \\
\text { resource } \\
\text { sources }\end{array}$ & $\begin{array}{c}\text { Requires a } \\
\text { large number } \\
\text { of different } \\
\text { types of } \\
\text { resources }\end{array}$ & $\begin{array}{l}\text { Requires the } \\
\text { possibility of } \\
\text { attracting } \\
\text { specific types } \\
\text { of resources } \\
\text { that at a } \\
\text { particular time } \\
\text { point may not } \\
\text { be available }\end{array}$ & $\begin{array}{l}\text { Allows to save } \\
\text { resources, but } \\
\text { does not allow } \\
\text { to clearly } \\
\text { predict their } \\
\text { required } \\
\text { amount in the } \\
\text { future }\end{array}$ \\
\hline
\end{tabular}

\section{Features of financial and economic security system strategic management}

In the scientific plane and at the applied level, there are disputes over whether the management of financial and economic security should be allocated in a separate direction of management activity, or its tasks can be effectively implemented within other types of management, for example, financial, personnel, crisis, strategic, innovation etc.

\subsection{Financial and economic security system management as an independent direction of management}

In the national scientific thought some approaches have already been developed to understand the category of financial and economic security management. I. Moyseyenko proposes to consider the security management system as "one of the functional areas of enterprise management (as a type of management organization), that is, as a process of planning, organization, motivation and control, necessary to achieve the goals of the enterprise. Security management - a component of enterprise management as a whole, which uses its best tools, is guided by the prevention of possible complications in the enterprise, providing sustainability of business activity" $[8$, p. 285].

Financial and economic security management involves the analysis, planning, regulation and control of organizational and economic activity of the enterprise in terms of minimizing the negative effects of destructive phenomena and threats $[11$, p. 105]. From another research position, the financial and economic security system management can be defined as "a set of interconnected and interacting elements of financial and economic management, which consists of subsystems and provides: protection of financial interests of economic entities, management of their financial activity, prevention of emergence and development of threats to financial security, reduction of their negative impact, management of financial risks, taking into account alternative ways of providing ensuring the security of enterprises through the application of financial instruments and methods of financial analysis and assessment of the financial state of the enterprise using the limit values of indicators and integrated assessments of its level" [11, p. 107].

The current realities of the business entities functioning and the specific features of the current stage of the Ukrainian economy development have shaped the peculiarities of the process of managing financial and economic security systems both at the tactical level and in the strategic perspective. They, in turn, demonstrate the disadvantages of existing management mechanisms. Disadvantages of financial and economic security management are: fragmentation of security systems; orientation of managerial decisions to eliminate the consequences of threats, rather than counteracting their occurrence or control of potential sources of danger and risk formation; saving of resources (labor, informational, 
financial, time) on security-oriented measures; lack of documents that would establish and clearly regulate the policy of financial and economic security management; low level of training of specialists, who are assigned the tasks of security management, lack of practical experience in this field, and the establishment of an excessive number of different-directional responsibility vectors in specific areas of security; lack of effective methodological tools for assessing the current level of financial and economic security and its forecasting in the future; low level of the managers awareness of the entire spectrum of threats and risks for the state of financial and economic security; lack of practice of forming risk maps and risk catalogs within the framework of risk management procedures; contradictory interests of various categories of stakeholders; the absence of norms of financial and economic security that provokes the problem of interpreting its state from different managerial positions; the lack of standards of financial and economic security, which would propagate guidance for the organization of its various subsystems; low effectiveness of the mechanism of stimulation of persons involved in the management of financial and economic security, to faithfully carry out their duties.

We offer the following approach to the financial and economic security management (Fig. 1).

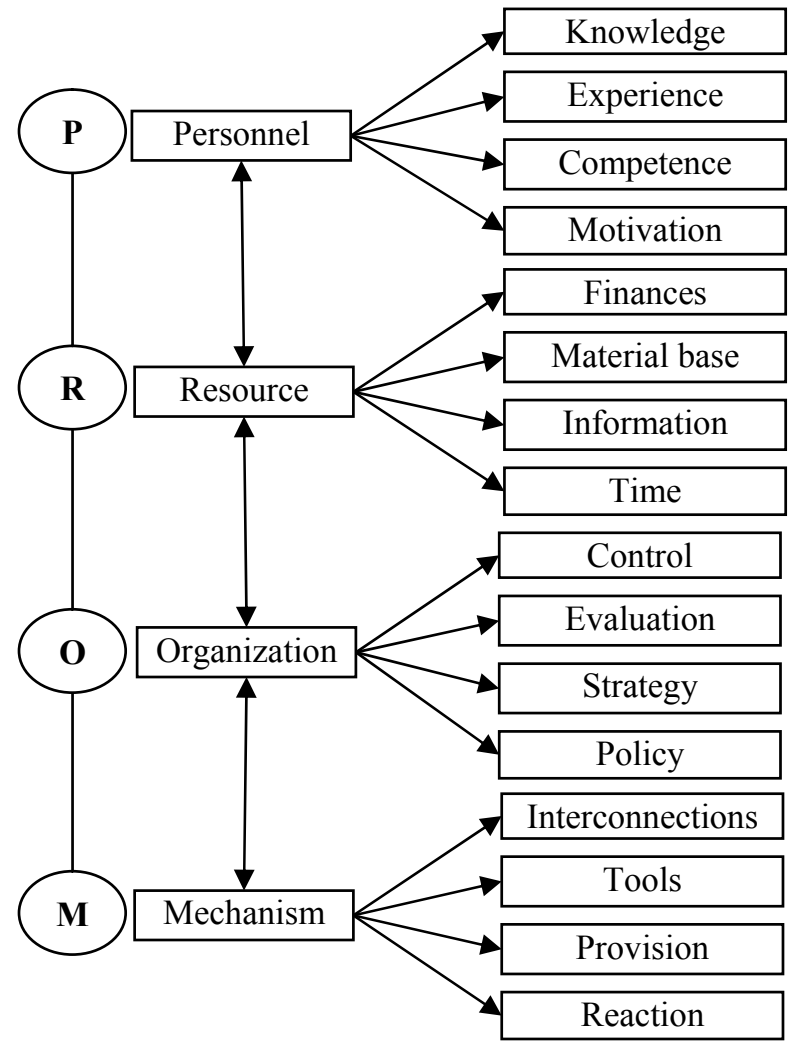

Fig. 1. The 16-component model of financial and economic security management (PROM).

Suitable for managing any system of financial and economic security on macro or micro level, universal, specific, complex, fragmentary one - the proposed model is able to provide the optimal distribution of available resources to ensure the security and to achieve the goal of creating and maintaining financial and economic security system in the strategic perspective. As the main goal of the system of financial and economic security of business, researchers name "to ensure its sustainable and maximally effective functioning, creating a high potential for development and growth in the future" $[20$, p. 146]. Thus, the need for strategic management is already laid in the very existence of the system of financial and economic security.

\subsection{The essence of the process of financial and economic security system strategic management}

The strategy of financial and economic security is the development of a long-term plan to ensure the achievement of the goals, objectives of the enterprise, in particular the provision of financial and economic security, as well as planning of resource allocation in conditions of constant instability of the environment and adaptation to protect it from influence threats, risks and achieve normal and safe functioning of it [21]. The strategy of financial and economic security involves defining the goals and objectives of the system of financial and economic security, directions for their solution, as well as the forms and methods of applying the appropriate forces and means, the possibility of their rearrangement, creating the necessary reserves for the neutralization and localization of possible threats [17]. According to O. Vivchar, the strategy of financial and economic security should include: characterization and classification of internal and external threats to economic security; definition and monitoring of factors that undermine the stability of the financial situation; definition of criteria and parameters that characterize financial and economic interests and meet the set requirements; the formation of financial and economic policies and the necessary mechanism that eliminates or facilitates the operation of factors that undermine the stability of the system of financial and economic security; main directions of financial and economic security; financial and economic security system management, coordination of activities and management to ensure financial and economic security at all levels [20, p. 148-149]. As emphasized by I. Dotsenko and O. Melnychuk, the goal of financial and economic security strategic management is to strengthen financial and economic security by minimizing the impact of destabilizing factors [22]. Thus, under the strategic management of the system of financial and economic security, we offer to understand the process of identifying long-term goals of the functioning of financial and economic security system in the conditions of influence on it of existing and potential threats to the external and internal environment, a set of actions on the implementation of the concept and policies of financial and economic security in the long-term perspective through a set of strategies that can be adjusted in accordance with the requirements of time and the specific conditions and circumstances that affect the normal activities of the object of protection. Taking into 
account the operating conditions that currently have domestic enterprises and the national economy as a whole, it is advisable to develop several alternative strategies for managing financial and economic security depending on the strategic priorities of the economic system functioning.

\section{Three-vector model of strategic management of the system of financial and economic security: micro and macro level}

Based on our own experience, on scientific achievements of domestic and foreign scientists and on the results of expert surveys of practitioners, we can propose three directions of the implementation of the tasks of the financial and economic security strategic management at the micro and macro levels, which take into account existing realities and national features of securityoriented management at the beginning of 2019.

A Strategy for achieving financial and economic security based on branding, image and reputation (BIR Strategy). The essence of the strategy is to give priority to the information and interface components of the financial and economic security system, to implement measures for the full transparency of the results of activities aimed at ensuring financial and economic security. The main vector of influence is reputation and image risks. A high level of financial and economic security is positioned as a brand of a business entity, region or state, which promotes a positive attitude by counterparties, clients, and government structures. The loyalty of staff is in a big importance, the management's policy is aimed at the dissemination of positive information about the subject, its social significance. Ratings are introduced to establish a specific position of the enterprise, institution, organization among other economic entities on the basis of indicators of the effectiveness of providing financial and economic security, or among other states at the international level in the study of problems of national financial and economic security.

Strategy for achieving financial and economic security through partnerships with stakeholders and ensuring their interests (PIS Strategy). The essence of the strategy is to ensure maximum satisfaction of the economic needs of those who interested in the results of the subject's activities through the formation of a safe environment for their implementation. Matrixes of influence and needs of stakeholders are developed, some of stakeholders representatives can be involved in the management of financial and economic security under the conditions of personnel outsourcing and leasing. Certain categories of stakeholders are actively involved in assessing the level of financial and economic security as experts. The purpose and specific directions of financial and economic security management are determined depending on the stakeholders interests.

Strategy to achieve the state of financial and economic security through the interconnection of experts, control and standardization (Strategy of the
ECS). The essence of the strategy is to introduce standards for the financial and economic security management at the state level or at the level of individual business structures and follow them. A significant role is played by the control of the state of financial and economic security, ongoing monitoring of its level, and new threats to the system of financial and economic security at the present time and in the future. To specify the external risks of the subject, experts are involved. The expert opinion in this strategy is important, as the emergence of the system of financial and economic security leads to the fact that the use of only mathematical tools and security policies to form information support for making managerial decisions is insufficient. Security-oriented solutions often have to be taken situationally, promptly, objectively, that it is possible only with the involvement of experts in the process of financial and economic security system management.

Of course, the use of any of the proposed strategies in the "pure form" is less effective than their weighted combination. However, the selection of specific vectors for the strategic management of the financial and economic security system at the level of top management or civil servants depends on the current and projected conditions in which the system of financial and economic security will operate and develop in the future.

\section{Conclusions}

According to the results of the study, system of financial and economic security is proposed to be understand as a set of elements, the interaction of which between themselves and with external actors can form such an environment of the functioning of a particular object, which will enable it to achieve the economic goal of its creation and implementation of the economic and financial interests of its stakeholders, regardless the existence and negative impact of threats on its current state and performance.

We offer the 16-component model of financial and economic security management (PROM), that is suitable for managing any system of financial and economic security - macro or micro level, universal, specific, complex, fragmentary. The proposed model is able to provide the optimal distribution of resources available to the entity to ensure its security and to achieve the goal of creating and maintaining its financial and economic system in the strategic perspective.

We can propose three directions of the implementation of the tasks of the financial and economic security strategic management at the micro and macro levels: the BIR Strategy, the PIS Strategy and the Strategy of the ECS.

\section{References}

1. Pro Stratehiyu natsionalnoyi bezpeky Ukrayiny (About the Strategy of national security of Ukraine). https://zakon.rada.gov.ua/laws/show/105/2007 (2007). Accessed 21 February 2019 
2. Pro Stratehiyu natsionalnoyi bezpeky Ukrayiny (On the Strategy of national security of Ukraine). https://zakon.rada.gov.ua/laws/show/287/2015 (2015) Accessed 26 February 2019

3. Schimmel, K., Liu, S., Nicholls, J., Nechval, N.A., Yi-Lin Forrest, J.: Economic security under disturbances of foreign capital. Adv. in Syst. Sc. and Appl. 17(2), 14-28 (2017)

4. Athanasoulis, S., Shiller, R., Van Wincoop E.: Macro markets and financial security. FRBNY Ec.pol. rev. 4, 21-39 (1999)

5. Baum, C.F., Pundit, M., Ramayandi, A.: Capital flows and financial stability in emerging economies. ADB, 522, 23 (2017)

6. Wysokińska-Senkus, A., Raczkowski, K.: Economic security in the context of sustainability. Aleksandras Stulginskis Univ., 6(1), 454-462 (2013)

7. Kahler, M.: Economic security in an era of globalization: definition and provision. The Pac. Rev. J., 17/4, 485-502 (2004)

8. Moyseyenko, I.P.: Systemnyy mekhanizm upravlinnya finansovo-ekonomichnoyu bezpekoyu pidpryyemstva (Systemic mechanism of financial and economic security management of the enterprise). Sc. Her. of LSU of Int. Af., 1, 284-291 (2013)

9. Cheberyako, O.V., Kryvovyaz, M.A.: Ekonomikoteoretychna sutnist systemy zabezpechennya finansovoyi bezpeky pidpryyemstva (The economic and theoretical essence of the system of financial security of the enterprise). Ec and the state J., 11, 94-97 (2015)

10. Zachosova, N.V. (ed.): Formuvannya systemy ekonomichnoyi bezpeky finansovykh ustanov (Formation of the system of economic security of financial institutions). PP Chabanenko Yu.A., Cherkasy (2016)

11. Kopylyuk, O.I., Muzychka, O.M.: Formation of the system of financial and economic security of business structures. Her. of LCA, 48, 104-109 (2015)

12. Kvasova, O.P., Khimich, H.O., Dehtyar, A.S.: Finansovo-ekonomichna bezpeka yak systema (Financial and economic security as a system). Interscience J., 12(2), 70-73 (2016)

13. Lohvynenko, M.I., Borysova, A.M.: Finansovoekonomichna bezpeka pidpryyemstva: deyaki aspekty terminolohiyi (Financial and economic security of the enterprise: some aspects of terminology). Forum of law, 1, 618-621 (2013)

14. Metodychni rekomendatsiyi do otsinyuvannya rivnya ekonomichnoyi bezpeky Ukrayiny (Methodological Recommendations for Calculating the Level of Economic Security of Ukraine). https://zakon.rada.gov.ua/rada/show/v1277731-13 (2013). Accessed 23 February 2019

15. Dubyna, M.V.: Kontseptualni zasady zmitsnennya finansovo-ekonomichnoyi bezpeky derzhavy cherez aktyvizatsiyu diyalnosti systemy parabankivskykh poserednykiv (Conceptual principles of strengthening of financial and economic security of the state through activization of the system of parabank intermediaries). Bul. of ChTTU. 3, 188196 (2014)

16. Yakymova, A.M., Holovkova, L.S.: Suchasni problemy formuvannya systemy finansovoekonomichnoyi bezpeky zaliznychno-transportnoho kompleksu Ukrayiny (Modern problems of the formation of the system of financial and economic security of the railway-transport complex of Ukraine). Col. of sc. works of NU of St. Tax Ser. of Ukraine. 1, 56-69 (2015)

17. Hrynkevych, S.S., Koknayeva, M.O.: Formuvannya systemy upravlinnya finansovo-ekonomichnoyu bezpekoyu torhovelnoho pidpryyemstva (Formation of the financial and economic security management system of a trading enterprise). Her. of Academy of Customs Service of Ukraine. 1, 126-131 (2012)

18. Mishchuk, O.V.: Doslidzhennya sutnosti finansovoekonomichnoyi bezpeky pidpryyemstva ta stratehiya upravlinnya neyu (Investigation of the essence of financial and economic security of the enterprise and its management strategy). FESM. 1, 4-9 (2015)

19. Ibrahimov, E.E.: Teoretychni pidkhody do vyokremlennya skladovykh systemy ekonomichnoyi bezpeky pidpryyemstva (Theoretical approaches to the isolation of components of the system of economic security of the enterprise). Sc. Her. of IHU. 11, 94-96 (2015)

20. Vivchar, O.: Spetsyfika upravlinnya systemoyu finansovo-ekonomichnoyi bezpeky biznesu v umovakh turbulentnosti ekonomichnykh protsesiv (Specificity of management of the system of financial and economic security of business in the conditions of turbulence of economic processes). Gal. Ec. Newsl. 2, 144-150 (2015)

21. Cherevko, O.V.: Stratehichne upravlinnya finansovo-ekonomichnoyu bezpekoyu pidpryyemstva (Strategic management of financial and economic security of an enterprise). EE. 2. http://nbuv.gov.ua/UJRN/efek_2014_2_83 Accessed 26 February 2019

22. Dotsenko, I.O., Melnychuk, O.P.: Stratehichne upravlinnya finansovo-ekonomichnoyu bezpekoyu pidpryyemstva (Strategic management of financial and economic security of the enterprise). SR. 3, 7984 (2018) 